\title{
As Habilidades e Competências a Necessárias ao Professor em Modalidade Blended Learning
}

\author{
Rafael H. N. Diniz ${ }^{1}$ \\ ${ }^{1}$ Núcleo de EaD FAPAM Virtual - Faculdade de Pará de Minas - FAPAM \\ Pará de Minas - MG - Brasil \\ \{rafael.diniz@fapam.edu.br
}

\begin{abstract}
This article presents the report of lived experience involving the coordination of a Distance Education nucleus of a private Faculty in the interior of Minas Gerais. It will list the challenges encountered and the improvements to be implemented regarding the teacher's role in training students in some subjects in blended learning format.
\end{abstract}

Resumo. O presente artigo apresenta o relato de experiência vivenciada envolvendo a coordenação de um núcleo de Educação a Distância de uma Faculdade particular do interior de Minas Gerais. Nele serão listados os desafios encontrados e as melhorias a serem implementadas com relação ao papel do professor com relação a formação de estudantes em algumas disciplinas em formato blended learning.

\section{Introdução}

O avanço tecnológico tem transformado a sociedade, causando diversas mudanças sociais. Conforme Teixeira (2016), a área de educação precisa refletir como se adequar frente ao uso das tecnologias. A educação em sua modalidade a distância tem conseguido prosperar no Brasil mediante desafios como: distâncias continentais dentro do país e valor reduzido dos cursos para o ensino superior. Para Tapscott \& Williams (2010), a aprendizagem baseada em transmissão de conhecimentos não reflete os anseios da nova geração que adentra ao cenário econômico global. Desta forma, a mudança de modalidade sem o devido planejamento ou adequação pode refletir em situações de desgosto e desânimo dos discentes. Desta forma, o presente trabalho apresenta relato de experiência ocorrido em uma instituição de ensino particular do centro-oeste de Minas Gerais, onde foi analisado e detectado as competências e habilidades necessárias para que um docente torne-se atuante no processo de educação a distância.

\section{Desenvolvimento}

A análise ocorreu ao longo de dois anos, desde a implantação de disciplinas virtuais nas 
matrizes de curso da Faculdade de Pará de Minas - FAPAM. A faculdade conta com oito disciplinas virtuais que totalizam $20 \%$ da carga horária dos cursos superiores da instituição. Desta forma, são abordados conteúdos transversais e de formação geral, tais como: Português Instrumental (niveladora), Metodologia Científica, Filosofia e Ética, Sociologia e Antropologia, Educação Ambiental e Desenvolvimento Sustentável, Direito, Cidadania e Responsabilidade Social, Empreendedorismo e Libras. A pesquisa teve o objetivo de analisar utilizando de questões aplicadas aos alunos através de um formulário de pesquisas (survey), quais as habilidades necessárias para um docente na modalidade "Blended leaning" . Desta forma é possível perceber dois fatores reconhecidos claramente pelos discentes nas aulas blended learning: conteúdos relevantes e a preparação de encontros presenciais diferenciados. Desta forma, as dificuldades desta modalidade encontram-se atrelada a qualidade de um projeto de Educação a Distância $(\mathrm{EaD})$ + participação docente. Um projeto $\mathrm{EaD}$ de qualidade deve possuir o compromisso de fornecer materiais que estimulem de diversas maneiras os estudantes como exemplo: vídeos, livros, infográficos, desafios, materiais complementares e atividades que ocorram de forma contextualizada. Assim, cria-se uma base para que nos momentos de presencialidade os estudantes possam aplicar os conteúdos vistos. Daí a enorme responsabilidade e importância do docente no processo. Além da seleção de estímulos para aprendizagem do estudante, os momentos de presencialidade devem ser planejados e que promovam ações lúdicas. Grande parte dos alunos entrevistados relatam que a qualidade da disciplina está atrelada ao momento de presencialidade. Desta forma, uma retomada de conteúdos por si só não é visto pelos alunos entrevistados como fator motivador para os encontros. Neste caso, cabe ao docente promover atividades contextualizadas de forma com que a disciplina não se torne apenas um emaranhado de arquivos em um repositório. Desta forma, o discente percebe que as disciplinas virtuais além de instigarem o aprendizado através dos recursos tecnológicos, promovem encontros verdadeiramente proveitosos e aplicáveis a sua vida, além do desenvolvimento de competências fundamentais no Século XXI que é a capacidade do uso de recursos tecnológicos para os estudos e capacitações e a autonomia.

\section{Conclusão}

Após a análise dos questionários respondidos pelos discentes e da análise feita com as tutoras da disciplina, foi possível perceber que o sucesso para uma disciplina em modalidade "blended learning" é uma composição de etapas que devem ser muito bem planejados. A responsabilidade em organizar os conteúdos e preocupar-se com ações que permitam que a presencialidade seja participativa é um desafio para os docentes. Ainda sobre a temática, convém que a instituição forneça estímulos para a realização de atividades lúdicas como: oficinas, workshops e cursos formativos. Desta forma, é necessário reforçar aos discentes a necessidade do empenho e engajamento nos estudos 
VIII Congresso Brasileiro de Informática na Educação (CBIE 2019)

Anais do VIII Workshop de Desafios da Computação aplicada à Educação (DesafIE 2019)

para que cheguem preparados e cientes dos conteúdos através de atividades que serão disponibilizados pelos docentes, contribuindo assim para uma atividade criativa, participativa e responsável por ambas as partes.

\section{Referências}

Tapscott, D.; Williams, A. D. Innovating the 21st-Century University: It's Time! Educause Review, January/February 17-29, 2010. Disponível em: <https://www.educause.edu/ir/library/pdf/ERM1010.pdf>. Acesso em: 15 abr. 2014.

Teixeira, T.F. Semipresencial: uma modalidade de ensino superior transformadora e inclusiva. Maiêutica, nº 1, v. 4, p. 167-174, 2016. 